\title{
FEEDLOT PERFORMANCE AND CARCASS CHARACTERISTICS OF ZEBU CATTLE IN THE MALI SAHEI, ZONE II. EFFECT OF UTILIZATION OF SUGARCANE TOPS (Saccharum officinarum) AS BASAL DIET
}

\author{
E. A. ADEBOWALE, S. LEGEL ${ }^{*}$ and K. DOBEL ${ }^{*}$ \\ Institute of Agricultural Research and Training \\ Obafemi Awolowo University, Moor Plantation, \\ P.M.B. 5029, \\ Ibadan, Nigeria.
}

(Received 29 September 1986, accepted for publication 29 January 1987).

\begin{abstract}
A feeding trial to evaluate the performance of finishing steers fed mainly on sugarcane tops with or without cottonseed and molasses was conducted in Niono, Mali during the dry season. 96 Zebu steers. weighing between 220 and $250 \mathrm{~kg}$ were randomly alloted to four groups of twentyfour steers each.

The performance parameters compared were: feed intake, rate of gain, feed conversion and carcass characteristics. The differences observed for feed intake, rate of gain and feed conversion appear to be more related to roughage level rather than source. There were no nutritional disorders. Results from this initial feeding trial indicate that a sugarcane - derived feedstuffs can be used to constitute a major component of finishing steer rations particularly in the dry areas of the tropics where sugarcane tops are regarded as wastes.
\end{abstract}

\section{INTRODIJ'IION}

The need to produce beef catte at a faster rate than hitherto and the necessity to become less dependent on importation of beef in the Mali has become very oxvious. The belief that the local breeds of beef cattle are slow growing and late maturing is no longer auspicious. The pattern of becf cattle management in Mali is based mainly on natural vegetation with nomadism as a system of managament. However, the main problem of utilizing the natural pasture lies in its insufficiency because of the prolonged hot, dry season. Under this system it is not uncommon to get a weight gain of less than $40 \mathrm{~g} /$ day throughout a whole year for the cattle (Legel and Dobel, 1977).

The cultivation of fodder in the Sahel zone of Mali is low and increased beef production must be accompanied by improved pasture. Radau (1972) enumerated the possibilities of increased forage production. Some quantity of agro-industrial byproducts and farm wastes are available. These include milling products of rice, sugarcane and cottonseed. The cattle, sheep and goats of the nomadic herdsmen and some settled farmers with a small number of ruminant animals generally feed on some of these byproducts particularly of the agricultural farms. However, there is a dearlh of knowledge as to the utilization of sugarcane tops which are available in large quantities after processing in the Sahel zone of Mali. Although sugarcane (Saccharum officinarum) can produce the greatest yield of readily available energy per hectare, its use as a crop is generally restricted to sucrose production for

* Institute of Tropical Agriculture, Department of Animal Production, University of Lciprig 7113 Markkleeberg Raschwitzer Sirasse 16 German Democratic Republic.

Nigerian Journal of Animal Production 13(1986):64-69 
..man consumption. Independent of pplying carbohydrate for human $\rightarrow i$, sugarcane offers an alternative $\therefore$ for animal feed production in $\therefore$ tropics and subtropics, due to semarkable photosynthetic ability $\because$ the plant. A major limitation in sing the energy-rich mature cane or ine tops for animal feeding is the eavily lignified rind layer, the preance of which lowers the nutritive alue of the remainder of the plant. This paper therefore highlights the zossibilitics of intensive fecding of eef cattle using sugarcanc tops as oghage in addition to rice bran, $\therefore c e$ meal, cottonsecd and molasses wich are all available in Mali.

\section{MATLRIALS AND METHOISS}

Animals and their management:

96 Kebu stecrs of the Maure and peulh brecels with ages between 48 and 50 months weighing between 220 and $250 \mathrm{k}:$ were used for the experi-inent which took place between the months of December and June. The animals were selected on the basis of uniformity in atge and weight from the Station d'Elevage et de Preherches
Cootechnique du Sahel, Niono in the Dougabougous Region of Mali. The research Station lies between latitude $12^{\circ} \mathrm{N}$ and $13^{\circ} \mathrm{N}$ and longitude $7 \% \mathrm{E}$ and $8{ }^{\circ} \mathrm{E}$ at the altitude of about 300 metres above sea level. It is within the Sahel zone with an average annual rainfall of $900 \mathrm{~mm}$. Rainy season extends from June to September with a mean maximum temperature ranging between $30^{\circ} \mathrm{C}$ in July to $40^{\circ} \mathrm{C}$ in May. During the preliminary period of four wecks, all animals were allowed to get uscd to their environment and feeding regime.

\section{Diets and Plan of Experiment:}

24 steers (12 each from Maure and Peulh) weie allocated to each of the diets (table 1). The basic fodder ( $18 \mathrm{~kg}$ of sugarcane tops per animal) was the same for all groups. However, the additional by-products were different for all the groups. The ration was given twice per day. The remainder was weighed back daily. For this expcriment, Dict $D$ was used as the control since a few farmers in the country have started to use the diet during the dry season. Water was also supplied ad libitum.

\section{TARLE 1 .}

\section{Components of experimental finishing rations fed to Zebu steers}

\begin{tabular}{|c|c|c|c|c|}
\hline$\therefore 5(\mathrm{~kg} / \mathrm{head} / \mathrm{day})$ & $A$ & $B$ & $C$ & $D$ \\
\hline$\therefore$ ircane tops & 18 & 18 & 18 & 18 \\
\hline$: \equiv \mathrm{bran} / \mathrm{meal}$ & 4 & & 4 & 4 \\
\hline =onseed & - & 2.5 & 2 & \\
\hline$\therefore$ Eses & .... & 1.0 & & 1 \\
\hline$\because$ seolus lathyroides & 3 & - & .- & \\
\hline - ilated ME (MJ/kgDM) & 9.2 & 11.2 & 10.1 & 9.2 \\
\hline uiated DCP (g/kgDM $)$ & 40.8 & 45.1 & 48.2 & 31.5 \\
\hline
\end{tabular}

- Erbaceous, annual, erectly branched plant with leaves trifoliate, leaflets ovate or lanceolate. Legel (1983)

?ed a $19.2 \%$ crude protein at 4 months with $15-26 \mathrm{~g} / \mathrm{W}_{\mathrm{kg}} .75$ digestible dry matter intake per day for

$\because$ - Setabolizable Energy.

: Digestible Crude Protein: 
The feeding trial was conducted for about 25 weeks and dry matter (DM) in take was daily recorded.

\section{Liveweight changes:}

Weights of three consecutive days were taken prior to the first day of trial followed by monthly weighings. Weights were obtained in the moming before feeding and watering.

\section{Carcuss evaluation:}

At the end of the feeding trial, ten (10) steers per group were transported by road to the slaughter-house at Bamako (9 hours joumey). Slaugh ter: ing was 24 hours after the last feeding.

\section{Analytical Procédure:}

The rations and ingredients were analysed for proximate analysis using the AOAC (1975) methods. Resufts were statistically evaluated by analysis of variance (Steel and Torrie, 1960). and the Duncan multiple-range test was used to detect differences among means.

\section{RESULTS AND DHCUSSION -}

Nutritive value of the diets:

The chemical composition and -. feediag walue of the four diets and their components are shown in table. 2. As shown by the proximate andy- sis, the crude protein and crude fibre values: of the Mali ingredients are similar to those obtained in. Nigeria (Adcbowale, 1985). However, the ME values obtained are higher than those normally obtained in many parts of Nigeria.

Diets $A-D$ are isonitrogenous and except for Diet D isocaloric. Crude fibre values also vary between $29.5 \%$ . and $35 \%$.

Feedlot Performance:

Feed intake and animal performance data are presented in table 3 .

Analyses motring liveweight alone were conducted on a per animal basis whike those involving afeed were on a per group basis, since animals were weighed individually but feed consumption was mersured per group.

fverage DM intake was higher in the control diet $\left(115: 5 \mathrm{~g} / \mathrm{w}_{\mathrm{kg}}^{/ 5}\right)$ than in the test diets and significantly. higher $(\mathrm{P}<0.05)$ than Diet B $(98.9 \mathrm{~g} /$ $W_{k y} 75 ;$ which had cottonseed and molasses. That is, the animals consumed sreater quantities of diet of higher roughage.. This observation is most likely as a result of reduced digestible energy (DE) intake from the high roughage diet. It is well known that cattle on ad thitwm feeding will attempt to equalise their

TABLE ?.

\section{Chemical eomperition of some atro-indutrial by-product and their compounded rations fod Zebu steers in Mali.}

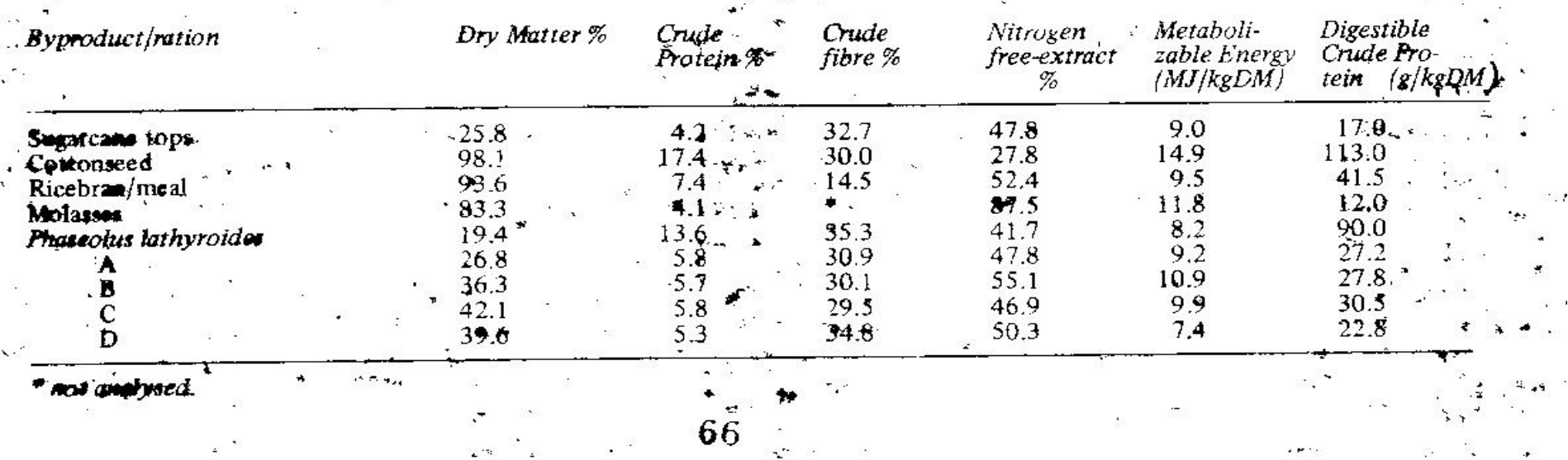


ADEBOWALE $E T A L$

TABLE 3.

Feedilot performance of finishing Zeòu steers

\begin{tabular}{|c|c|c|c|c|c|}
\hline Parameter - & $A$ & $B$ & $C$ & $D$ & $\begin{array}{l}\text { SEM and significance } \\
\text { difference. }\end{array}$ \\
\hline No. of steers & 2406 & 24.00 & $2400^{\circ}$ & 24.00 & \\
\hline Days of experiment & 18000 & 180.00 & 18000 & 180.00 & \\
\hline Average initial weight $(\mathrm{kg})$ & 224.00 & 235.1 & 240.70 & 232.20 & \\
\hline ,Average frnal weight $(\mathrm{kg})$ & 288.90 & $3 \longdiv { 7 . 4 }$ & 336.40 & 299.00 & \\
\hline DM intake $\left(\mathrm{g} / \mathbf{w}_{\mathrm{kg}} \mathrm{g}^{75 / \mathrm{d}}\right)$ & $104.6 \mathrm{ab}$ & $98.9 \mathrm{c}$ & $101.4 \mathrm{abc}$ & $115.5 a$ & $3.65^{*}$ \\
\hline Avg. daily gain ( $\mathrm{kg} /$ day) & $0.37 \mathrm{~b}$ & $0.46 \mathrm{ab}$ & $0.55 \mathrm{a}$ & $0.41 \mathrm{ab}$ & $0.039^{*}$ \\
\hline *Cool. & $0.50 \mathrm{abc}$ & $0.43 \mathfrak{c}$ & $0.59 \mathrm{a}$ & $0.52 \mathrm{ab}$ & $0.034^{*}$ \\
\hline **Hoi, dry season & 0.24 & 0.48 & 0.50 & 0.30 & $0.065 \mathrm{NS}$ \\
\hline $\mathrm{DM}$ intake/kg gain & 18.60 & 14.60 & $13.4 n$ & 20.50 & $1.67 \mathrm{NS}$ \\
\hline Efficiency of feed utilization (\%) & 5.40 & 6.9 & 7.50 & 4.90 & $0.61 \mathrm{NS}$ \\
\hline
\end{tabular}

${ }^{*} a, b, c$. Different letters within the same row are significantly $(P<0.05)$ different

NS Not significant

SEM Standard error of mean

* Cool, dry season - temp. between $17^{\circ}$ and $36^{\circ} \mathrm{C}$ with $250 \mathrm{~mm}$ annual rainfall

** Hot, dry season - temp. between $24^{\circ}$ and $40^{\circ} \mathrm{C}$ with rainfall below $1000 \mathrm{~mm}$.

DE consumption (Montgomery and Baumgardt, 1965). The intake of the slightly higher roughage ration did suggest that on high roughage rations, rumen capacity may restrict the animals' ability to maximise its digestible energy intake.

The rates of gain for all groups have been separated into hot, dry season when temperature ranged between $24^{\circ}$ and $40^{\circ} \mathrm{C}$ with almost no rainfall and cool, dry season with temperature ranging between $17^{\circ}$ and $36^{\circ} \mathrm{C}$ and about $250 \mathrm{~mm}$ annual rainfall. Liveweight gains obtained during the hot, dry season were significantly lower $(\mathrm{P}<0.05)$ than the cool dry season No differences were recorded between the treatments during the hot, dry season. However, during the cool, dry season, animals on diet $\mathrm{C}$ had the fastest growth rate of $0.59 \mathrm{~kg} /$ day which was significantly higher than Diet C $(0.43 \mathrm{~kg} /$ day $)$. Generally, the rates of gain for all groups over the 25 week-trial were generally slow ranging between $0.37 \mathrm{~kg} /$ day (Diet A) to $0.55 \mathrm{~kg} /$ day (Diet $\mathrm{C}$ ). The inclusion of cottonseed and/or molasses in the diets seemed to have contrihuted to a faster growth rate for Diets $B$ and $C$ although the high ambient tempera- ture seemed to have blurted these differences slightly during the hot, dry season. It should be noted that the protein level of the dicts were generally low even for finishing steers. Protein supply is particularly critical with sugarcane-based rations as the cane contributes negligible amounts of protein (Donefer et al., 1973). In a similar experiment by Donefer et al. (1973), maize supplementation resulted in significantly greater gains than molasses indicating that some supplemental energy in the form of starch might be preferable to the predominant sugars in the sugarcane tops/molasses combination Again, the slow rate of gains might be due to the fact that the animals were under a serious stress as is expected at Niono during this pericid of the year.

The amount of feed required fer unit of gains (feed conversion) increased particularly. with increasing lexels of roughage in the dict. This ranges between 13.4 (Diet C) to $20.5 \mathrm{~kg}$ $\mathrm{DM}$ intake $/ \mathrm{kg}$ gain for the control diet. However, there were no significant differences between the treatments. The efficiency of fecd utilization was very poor for all the diets. This may be because of the high 
roughage content of all diets since sugarcane tops formed the major component of the diets. It could also be due to the age of the animals (48 - 50 months) although the mature age of this breed of animals could be above 60 months.

\section{Carcass Characteristics:}

Results of the carcass parameters studied are shown in table 4 . However, unlike the feedlot performance characteristics which appear to be more related to the level of roughage, the mean carcass weight and dressing percentage did not show similar relationship. There were also no differences between the liveweight lost after transportation and fasting showing that the composition of the diets had no effect on loss in weight. However, the tendency of heavier animals to have higher losses during fasting was preponderant. The dressing percentage was gencrally between
$51 \%$ (Diet B) to $54.9 \%$ (Diet A) which is a little lower than those obtained under European conditions (Legel and Dobel, 1977).

It is pertinent to note that throughout this trial, there were no nutritional disorders recorded. Also, since the differences observed for the parameters studied were not affected by nutritional levels, it could be reasonably stated that the sugarcane tops could be satisfactorily used in the finishing ration of steers or maintaining the weight of stecrs during the dry season when pastures are not available. Finally, it is of course assumed that the use of a particular feeding programme (in this instance sugarcane tops/molasses/ cottonseed without maize) in any arca is not only dependent on animal response but alsó on cost analysis of all inputs, outputs, alternatives and most importantly availability.

TABLE 4.

\section{Ccarcass characteristics of finishing steers}

\begin{tabular}{|c|c|c|c|c|c|}
\hline Parameter & $A$ & $B$ & $C$ & $D$ & $\begin{array}{l}\text { SEM and Significance } \\
\text { difference }\end{array}$ \\
\hline $\begin{array}{l}\text { No. of steers } \\
\text { Avg. liveweight }(\mathrm{kg})\end{array}$ & $\begin{array}{c}10 \\
288.9\end{array}$ & $\begin{array}{l}10 \\
317.4\end{array}$ & $\begin{array}{c}0 \\
336.4\end{array}$ & $\begin{array}{c}10 \\
299.0\end{array}$ & \\
\hline $\begin{array}{l}\text { Liveweight after transportation } \\
\text { and fasting }(\mathrm{kg})\end{array}$ & 280.1 & 291.7 & 307.8 & 278.2 & \\
\hline Shrinkage $(\%)$ & 3.1 . & 8.1 & 8.5 & 7.0 & $1.23 \mathrm{NS}$ \\
\hline $\begin{array}{l}\text { Avg. carcass weight (hot) }(\mathrm{kg}) \\
\text { Cooling loss after } 24 \mathrm{hrs} .(\%)\end{array}$ & 156.9 & 152.7 & 109.9 & 150.8 & \\
\hline $\begin{array}{l}\text { Cooling loss after } 24 \mathrm{hrs} .(\%) \\
\text { Dressing } \%\end{array}$ & $\begin{array}{l}2.1 \mathrm{ab} \\
54.9 \mathrm{a}\end{array}$ & $2.4 a$ & $\begin{array}{l}1.9 \mathrm{~b} \\
54.1 \mathrm{ab}\end{array}$ & $\begin{array}{r}2.3 \mathrm{ab} \\
53.0 \mathrm{ab}\end{array}$ & $\begin{array}{l}0.11^{*} \\
0.82^{*}\end{array}$ \\
\hline
\end{tabular}

*a, b, c. Different letters within the same row are significantly $(P<0.05)$ different

NS Not significant

SEM: Standard error of mean.

\section{RE FE RENCES}

ADEBOWALE, E.A. (1985), Non-cunventional feed resources in Nigeriá

Nig. Fd. J. 3(1): $181-189$.

ASSOCIATION OF OFFICIA]_ ANALYTICAL CHEMISTS, A.O.A.C. (1975). Official methods of Analysis, 12th Ed. Washington, D.C.
DONEFER, E. JAMES, L. A. and LAURIE, C.K. (1973). Use of a sugarcanederived feedstuff for livestock. In Proceeding: III World Conference on Animal Production Melbourne, Australia.

LEGEL, S. (1983) Tropical forage legumes and grasses Part 1. Legumes. Arbeitsgruppe Lehr-Und Lermitted Markk- 
ADEBOWALE ET AL.

leeberg, GDR.

LEGEL, S. and DOBEL, K. (1977). Die Futtergrundlage der nomadischen rinderhaltung in der Sahelzone Afrikas und Moglichkeiten ihrer verbesserung unter besonderer Beruck sichtigung der Republik Mali.

Beitr. trop. Landwirtsch. Veterinarmed 15: 301.

MONTGOMERY, M.J. and BAUMGARDT, B.R. (1965). Regulation of food intake in ruminants. 1. Pellected rations varying in energy concentra- tion

J. Dairy Sci. $48: 569-574$.

RADAU, H. (1972) Uber die Futterpflanzenproduktion in der Republik Mali under besonderer Berucksichtigung des Feldfutterbaues. TeilZ: Der Feldfutterbau in Mali und seine pflanzenbaulichen Plobleme.

Beitr. trop. Landwirtsch Veterinarmed 10: 255

STEEL, R.G.D. and TORRIE, J.H. (1960) Principles and procedures of statistics. McGraw - Hill, New York. 